\title{
But is this really the 'parent' or 'guardian'? Practical strategies for consent to child research in South Africa
}

\author{
C M Slack, ${ }^{1}$ MA Clin Psych, PhD; A E Strode, ${ }^{2}$ LLM, PhD \\ ${ }^{1}$ HIV/AIDS Vaccines Ethics Group, School of Applied Human Sciences, University of KwaZulu-Natal, Pietermaritzburg, South Africa \\ ${ }^{2}$ School of Law, University of KwaZulu-Natal; HIV/AIDS Vaccines Ethics Group, University of KwaZulu-Natal, Pietermaritzburg, South Africa
}

Corresponding author:CM Slack (slackca@ukzn.ac.za)

\begin{abstract}
Research ethics committees (RECs) in South Africa may require consent from a parent or legal guardian for child research. In instances where an REC determines that parental or guardianship consent is required, how far should researchers go to establish if the accompanying adult is in fact the parent or guardian? Should researchers accept disclosures at face value, probe assertions that are made, or even call for supporting documentation? In this article we set out the facts research staff should possess, propose key questions they could ask, and recommend practical steps for uncertain cases. We recognise that a parental/guardianship consent strategy may not be appropriate in all instances, but do not debate that issue in this article. This article is confined to practical advice for researchers wishing to implement a parental or guardianship consent approach.
\end{abstract}

SAfr J BL 2016:9(1):35-38. DOI:10.7196/SAJBL.457

Research ethics committee (REC)s in South Africa (SA) are likely to require consent from a parent or legal guardian for child enrolment into clinical trials according to ethical norms in clinical trial guidelines. ${ }^{[1]}$ RECs may stipulate parental or guardianship consent for other child studies that are more than minimal risk, according to ethical norms in national guidelines. ${ }^{[2,3]}$ Of course, some RECs may stipulate mandatory parental consent for other child studies in compliance with recent legal norms, ${ }^{[4]}$ even though many commentators have argued against mandatory parental consent without the possibility of a waiver. ${ }^{[5,6]}$

This article does not debate the circumstances under which researchers should seek proxy consent from parents or guardians v. other adults such as caregivers; nor does it debate the conditions under which researchers should seek independent consent from child participants themselves in accordance with their evolving capacity to make reasoned choices and independent judgements. ${ }^{[7]}$ This article simply assumes that in some instances RECs will have determined that consent from a parent or legal guardian is required for child enrolment into a particular study, as per the ethical norms of the REC ${ }^{[1-3]}$ and as part of a comprehensive review of whether the protocol meets norms for ethical research as set out in the most recent ethical guidelines. ${ }^{[3]}$ See Table 1.

In instances where an REC has made a proper determination that parental or guardianship consent is required, how far should researchers go to establish if the accompanying adult is in fact the parent or guardian? Should researchers accept disclosures at face value, probe assertions that are made, or even call for supporting documentation? In this article we set out the facts research staff should possess, propose key questions they could ask, and recommend practical steps for uncertain cases. This operational detail is not contained in current ethical guidelines ${ }^{[3]}$ nor recent regulations issued by the Minister of Health. ${ }^{[8]}$
Table 1. Norms for child research set out in national ethical guidelines (Department of Health (DoH) 2015)

The participation of children is indispensable for the research

The research problem is of relevance to children

Taking part would not be contrary to the best interests of the child [new]

The research presents acceptable standards of risk for child participants

The research will take into account children's privacy interests [new]

The research will ensure abuse and neglect are reported [new]

The research will ensure thoughtful reporting of underage sex [new]

The research will seek appropriate permission for the research (consent from parent or legal guardian (LG), or from a substitute, or from children themselves are possible approaches depending on various factors)

The research will be reviewed by an REC with appropriate child expertise

\section{Implementing a parent and/or guardian consent approach}

In our view, taking reasonable steps to implement a parental or guardianship consent strategy means the following:

- Researchers should be aware of the current definition of 'parent', 'guardian' and 'caregiver' in SA because the accompanying adult may be of the view that they fall into these categories, when they do not meet the strict legal definition. As set out in a previous article, in law, a 'parent' is the biological or adoptive mother or father of a child, and is also generally the child's legal guardian with some specific exclusions, for example, a gamete donor. ${ }^{[7]} \mathrm{A}$ parent is the child's 'guardian' in most instances, firstly, if she is the biological 
mother of a child if she is over 18 (her mother will be the child's guardian if she is under 18). ${ }^{[7,9]}$ Secondly, if he is the biological father of a child in certain circumstances: these circumstances include he must have been or is over 18, married to the biological mother or was in a permanent life partnership at any time-point during her pregnancy or after the child's birth, or he has agreed to be identified as the child's father; or he has paid damages in terms of customary law; or he has paid for, or tried to pay for, the costs of raising the child. ${ }^{[7,9]}$ Another person may be the guardian if $\mathrm{s} / \mathrm{he}$ has been nominated for this position in a will written by the existing guardian or if they have been appointed as guardian by the High Court. ${ }^{[7,9]}$ Finally, a caregiver is a person who cares for a child with the implied or express consent of a parent or guardian and can include, for example, a foster parent, an aunt or a grandparent. ${ }^{[7,9]}$

- Research staff should ask questions to establish the nature of the relationship between the child and the accompanying adult, in a thorough yet non-interrogatory fashion. Research staff should present the rationale for asking questions. They could use words to this effect: 'Many adults may genuinely believe they are the parent or guardian because they take care of the child on a day-to-day basis, but they might not fall within the legal definition of a parent or guardian. We need to be able to tell the difference for this particular study'.

- Research staff should document answers to questions. Consent staff should document key aspects of the consent conversation, for future reference or for advice from senior research staff.
- Research staff should call for documentation, where doubt exists. In cases where there is doubt that the presenting adult meets the legal definition of a parent or guardian, research staff should call for documentation but in a way that maintains a respectful, trusting and transparent relationship with this important research stakeholder. ${ }^{[10-12]}$ They should explain that such requests are needed to meet REC requirements that permission is received from a strict subset of adults. Researchers should ensure that requests are not taken as a comment on the honesty or goodwill of the accompanying adult. ('As before, we recognise that many adults provide children with as much care as the actual parent, and sometimes more, but for this research we have to find adults who fit into a narrow legal definition of 'parent' or 'guardian', and documents would shed more light').

In the Tables below, we set out certain scenarios, as well as the knowledge that consent staff should have, probes they can use, and requests they can make for documentation in uncertain cases.

\section{Conclusion}

Where researchers need to obtain parental or guardianship consent, they should act reasonably by being aware of which adults legally fall into these two categories, by trying to assess whether accompanying adults factually fall into these two categories and by having some procedure for addressing uncertainty. The recommendations set out

Table 1. Accompanying female adult reports she is the parent

\begin{tabular}{llll}
\hline Scenario & Know & Ask & If in doubt, ask for: \\
\hline $\begin{array}{l}\text { A child is accompanied to the } \\
\text { research site by an adult female } \\
\text { who says she is the parent }\end{array}$ & $\begin{array}{l}\text { That a female over 18, who is the } \\
\text { biological mother of the child, is both } \\
\text { the parent and legal guardian }{ }^{[7]}\end{array}$ & $\begin{array}{l}\text { 'Are you over 18?' and 'are you the } \\
\text { biological mother' or 'did you give } \\
\text { birth to this child?' }\end{array}$ & An ID book \\
& & $\begin{array}{l}\text { If questions are answered easily, do } \\
\text { not call for documents }\end{array}$ & $\begin{array}{l}\text { A signed affidavit from a } \\
\text { respected community leader } \\
\text { on unabridged birth certificate } \\
\text { (from Department of Home Affairs) }\end{array}$
\end{tabular}

Table 2. Accompanying male adult reports he is the parent

\begin{tabular}{|c|c|c|c|}
\hline Scenario & Know & Ask & If in doubt, ask for: \\
\hline $\begin{array}{l}\text { A child is accompanied to the } \\
\text { research site by an adult male } \\
\text { who says he is the parent }\end{array}$ & $\begin{array}{l}\text { That a male over } 18 \text { who is the } \\
\text { biological father of a child is the parent } \\
\text { but is not automatically the legal } \\
\text { guardian }{ }^{[7]} \\
\text { To also be a guardian: } \\
\text { - he must be married to the child's } \\
\text { mother, or have been married to her } \\
\text { during the pregnancy, or any time after } \\
\text { the baby's birth or } \\
\text { - he was living with her in a committed } \\
\text { partnership at the time of the birth or } \\
\text { - he consented to being identified as the } \\
\text { child's father or } \\
\text { - he paid damages in terms of } \\
\text { customary law or } \\
\text { - he contributes or has contributed to } \\
\text { the child's upbringing and expenses. }{ }^{[7]}\end{array}$ & $\begin{array}{l}\text { 'Are you the biological father?' } \\
\text { 'Are you now, or were you ever married } \\
\text { to the mother when she was pregnant } \\
\text { or after the birth?' (civil or customary } \\
\text { marriage) } \\
\text { or 'Were you living with the child's } \\
\text { mother when the child was born?' } \\
\text { or 'Have you admitted to others that } \\
\text { s/he is your child?' } \\
\text { or 'Does the child use your surname?' } \\
\text { or 'Do you help with caring for her/him?' } \\
\text { or 'Do you help with paying for her/his } \\
\text { needs?' } \\
\text { If one of these questions can be } \\
\text { answered easily, then do not seek } \\
\text { documentation }\end{array}$ & $\begin{array}{l}\text { A signed affidavit from } \\
\text { a respected community } \\
\text { leader to attest to one of } \\
\text { the conditions } \\
\text { or } \\
\text { Ask for an unabridged } \\
\text { birth certificate (from } \\
\text { Department of Home } \\
\text { Affairs) }\end{array}$ \\
\hline
\end{tabular}


Table 3. Accompanying adult reports $s /$ he is the adoptive parent

\begin{tabular}{llll}
\hline Scenario & Know & Ask & If in doubt, ask for: \\
\hline $\begin{array}{l}\text { A child is accompanied to the } \\
\text { research site by an adult who } \\
\text { says s/he is the adoptive parent }\end{array}$ & $\begin{array}{l}\text { That if a woman or a man is the } \\
\text { adoptive parent of a child, they are } \\
\text { the parent and legal guardian }{ }^{[7]}\end{array}$ & $\begin{array}{l}\text { 'How did you come to be the adoptive } \\
\text { parent?' } \\
\text { 'Was this done through the courts or a social } \\
\text { worker?' } \\
\text { 'When was the adoption done?' }\end{array}$ \\
& $\begin{array}{l}\text { 'If there was a social worker, who were they?' } \\
\text { If these questions can be answered easily, } \\
\text { then do not seek documentation. }\end{array}$ \\
&
\end{tabular}

Table 4. Accompanying adult reports $s /$ he is the legal guardian

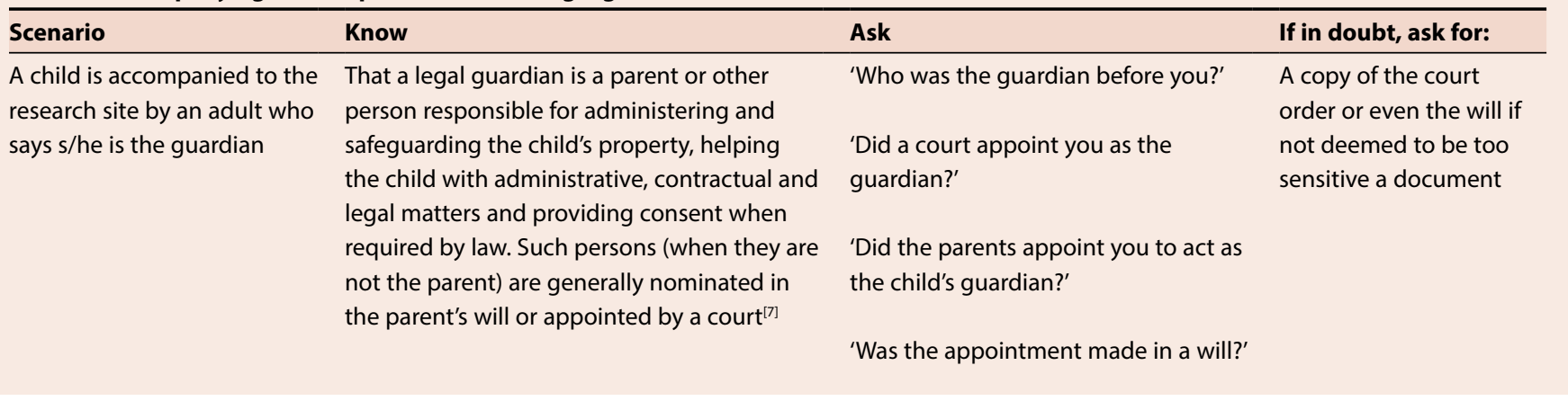

Table 5. Accompanying adult is likely to be a caregiver

\begin{tabular}{|c|c|c|c|}
\hline Scenario & Know & Ask & Take steps \\
\hline $\begin{array}{l}\text { A child is accompanied to the } \\
\text { research site by an adult who } \\
\text { is most likely the caregiver }\end{array}$ & $\begin{array}{l}\text { That caregivers include persons } \\
\text { providing day-to-day care with } \\
\text { the parent's permission, such as } \\
\text { foster parents, relatives (including } \\
\text { grandparents), and persons receiving a } \\
\text { childcare grant for a child }{ }^{[7]}\end{array}$ & $\begin{array}{l}\text { 'Do you care for the child with the } \\
\text { parent's permission?' } \\
\text { 'Do you receive a grant to care for } \\
\text { this child?' }\end{array}$ & $\begin{array}{l}\text { Where necessary (e.g. if there is no } \\
\text { parent/guardian) ask if the caregiver } \\
\text { is prepared to be appointed as the } \\
\text { guardian by a court, and refer them } \\
\text { to local legal services, such as a } \\
\text { campus law clinic }\end{array}$ \\
\hline
\end{tabular}

here were implemented successfully in a study funded by the European and Developing Countries Clinical Trials Partnership (EDCTP) that enrolled adolescents in an HPV vaccine trial at numerous sites in SA.

We do not submit that parental/guardianship consent is always the appropriate strategy and agree with the latest national ethical guidelines that in some instances a different consent approach will be acceptable. ${ }^{[3]}$ This article provides some advice to researchers who wish to meet their responsibilities when implementing a parental/ guardianship consent approach.

We acknowledge that asking for documentation in uncertain cases might exacerbate mistrust between the researcher and a key research stakeholder, inadvertently becoming a barrier to otherwise ethical child research. ${ }^{[13,14]}$ It is also possible that certain community members might perceive the law as side-lining important cultural norms. ${ }^{[15]}$ Therefore, researchers should share their experiences with various approaches, and stakeholder experiences of these approaches should be actively researched, including negative impacts, to allow adjustment and refinement.

Acknowledgements. Initial support for this research was made possible by funds from the EDCTP. The work described here was also supported by the National Institutes of Health (NIH) award number 1RO1 A1094586 (CHAMPS: Choices for Adolescent Methods of Prevention in SA). The content is solely the responsibility of the authors and does not necessarily represent the official views of the EDCTP or the NIH. It does not necessarily represent the views of any council or committee with which the authors are affiliated. Thanks also to Glenda Gray and Fatima Laher for discussion on this issue.

\section{References}

1. National Department of Health, South Africa. South African Good Clinical Practice guidelines. 2nd ed. Pretoria: NDoH, 2006. http://www.kznhealth.gov.za/research/ guideline2.pdf (accessed 15 May 2009).

2. National Department of Health, South Africa. Ethics in Health Research: Structures, Principles and Processes. Pretoria: NDoH, 2004. http://www.mrc.ac.za/ ethics/DOHEthics.pdf (accessed 15 May 2009)._National Department of Health, South Africa. Ethics in Health Research: Structures, Principles and Processes, 2nd ed. Pretoria: NDoH, 2015. http://www.mrc.ac.za/ethics/ethics.html (accessed 15 May 2015).

3. Republic of South Africa. National Health Act No. 61, Section 71. Pretoria: Government Printer, 2003.

4. Strode A, Richter M, Wallace M, Toohey J, Technau K. Failing the vulnerable: Three new consent norms which will undermine health research with children. S Afr J HIV Med 2014;15(2):46-49. DOI:10.4102/hivmed.v15i2.18

5. Zuch M, Mason-Jones AJ, Mathews C, Henley L. Changes to the law on consent in South Africa: Implications for school-based adolescent sexual and reproductive health research. BMC 2012;12(3):1-5. DOI:10.1186/1472-698X-12-3 
6. Strode A, Slack C. Using the concept of 'parental responsibilities and rights' to identify adults able to provide proxy consent to child research in South Africa. $S$ Afr J BL 2011;3(2):55-58.

7. Republic of South Africa, Department of Health. R378 Regulations Relating to Research with Human Subjects (published for public comment). Pretoria: Government Gazette No. 36508, 2013.

8. Republic of South Africa. Children's Act, No. 38. Pretoria: Government Gazette No. 28944, 2005.

9. Santelli JS, Smith Rogers A, Rosenfeld WD, et al. Guidelines for Adolescent Health Research: A Position Paper of the Society for Adolescent Medicine. J Adolesc Health 2003;33(5):396-409. DOI.1016/j.jadohealth.2003.06.009

10. UNAIDS/AVAC. Good participatory practice: Guidelines for biomedical HIV prevention trials. Geneva: UNAIDS, 2011. http://www.unaids.org/en/media/ unaids/contentassets/documents/unaidspublication/2011/JC1853_GPP_ Guidelines_2011_en.pdf (accessed 21 April 2012).
11. West SK, Ukpong M, Heise L. Community engagement in HIV prevention trials: Evolution of the field and opportunities for growth. Aids2031 background paper. Seattle: PATH publications, 2008. http://www.path.org/ publications/files/aids2031_comm_engage.pdf (accessed 21 November 2014).

12. DiClemente RJ, Ruiz MS, McDermott J. Barriers to adolescents' participation in HIV biomedical prevention research. J Acquir Immune Defic Syndr 2010;54(Suppl 1):S12-S17. DOI10.1097/QAl.0b013e3181e1e2c0

13. Nelson RM, Lewis LL, Struble K, Wood SF. Ethical and regulatory considerations for the inclusion of adolescents in HIV biomedical prevention research. J Acquir Immune Defic Syndr 2010;54(1):S18-S24. DOI:10.1097/QAI.0b013e3181e2012e

14. Jaspan $\mathrm{H}$, Soka $\mathrm{N}$, Strode $\mathrm{A}$, et al. Community perspectives on the ethical issues surrounding adolescent HIV vaccine trials in South Africa. Vaccine 2008;26(45):5679-5683. DOI.org/10.1016\%2Fj.vaccine.2008.08.033 